\title{
Pyruvate inhibits zinc-mediated pancreatic islet cell death and diabetes
}

\author{
I. Chang ${ }^{1}$, N. Cho' ${ }^{1}$, J.-Y. Koh ${ }^{2}$, M.-S. Lee ${ }^{1}$ \\ ${ }^{1}$ Department of Medicine, Samsung Medical Center, Sungkyunkwan University School of Medicine, Seoul, Korea \\ 2 Department of Neurology, University of Ulsan College of Medicine, Seoul, Korea
}

\section{Abstract}

Aims/hypothesis. We have shown that zinc ion $\left(\mathrm{Zn}^{2+}\right)$ in secretory granules of pancreatic beta cells could act as a paracrine death effector in streptozotocin-induced diabetes. As $\mathrm{Zn}^{2+}$ has been reported to perturb glycolysis, we studied if pyruvate could inhibit $\mathrm{Zn}^{2+}$-mediated islet cell death in vitro and streptozotocin-induced diabetes in vivo by normalizing intracellular energy metabolism.

Methods. Cell death was measured by quantitative viable cell staining and Hoechst/propidium iodide staining. ATP was measured by bioluminescence determination. Pyruvate was infused through the tail vein $1 \mathrm{~h}$ before streptozotocin administration. Betacell volume was measured by point counting of the insulin-containing cells.

Results. $\mathrm{Zn}^{2+}$ induced classical necrosis on MIN6N8 insulinoma cells which was associated with a rapid decline of intracellular ATP levels. Pyruvate inhibited
$\mathrm{Zn}^{2+}$-induced necrosis of insulinoma cells and depletion of intracellular ATP by $\mathrm{Zn}^{2+}$. Pyruvate did not inhibit other types of necrosis or apoptosis. Energy substrates such as oxaloacetate, $\alpha$-ketoglutarate and succinic acid dimethylester also attenuated $\mathrm{Zn}^{2+}$-induced insulinoma cell death. Methylpyruvate that does not generate $\mathrm{NAD}^{+}$in the cytoplasm or $\alpha$-ketoisocaproate that stimulates ATP generation exclusively in mitochondria also protected insulinoma cells from $\mathrm{Zn}^{2+}$-induced necrosis. Pyruvate infusion inhibited the development of diabetes by protecting beta-cell mass after streptozotocin administration.

Conclusion/interpretation. These results indicate that pyruvate inhibits $\mathrm{Zn}^{2+}$-induced necrosis of beta cells in vitro by protecting intracellular ATP levels and also streptozotocin-induced diabetes in vivo where $\mathrm{Zn}^{2+}$ has been reported to act as a paracrine death effector. [Diabetologia (2003) 46:1220-1227]

Keywords Zinc, ATP, pyruvate, apoptosis, necrosis.
Received: 5 December 2002 / Revised: 22 April 2003

Published online: 24 July 2003

(C) Springer-Verlag 2003

Corresponding author: M.-S. Lee MD PhD, Department of Medicine, Samsung Medical Center, Sungkyunkwan University School of Medicine, 50 Irwon-dong Kangnam-ku, Seoul 135-710, Korea E-mail: mslee@smc.samsung.co.kr

Abbreviations: STZ, streptozotocin; GAPDH, glyceraldehyde3-phosphate dehydrogenase; ROS, reactive oxygen species; NOD, non-obese diabetic; MTT, 3-[4,5-dimethylthiazol-2-yl]2,5-diphenyltetrazolium bromide; z-VAD.fmk, $N$-benzyloxycarbonyl-Val-Ala-Asp.fluoromethylketone; PI, propidium iodide; $\mathrm{Ab}$, antibody; TCA, tricarboxylic acid; SAD, succinic acid dimethyl ester; LDH, lactate dehydrogenase; KIC, $\alpha$-ketoisocaproate; BHA, butylated hydroxyanisole; PARP, poly(ADPribose) polymerase; RIP, receptor-interacting protein.
Zinc ion $\left(\mathrm{Zn}^{2+}\right)$ is highly concentrated in secretory granules of pancreatic beta islet cells $[1,2]$. We have previously reported that $\mathrm{Zn}^{2+}$ in secretory granules of pancreatic beta cells could act as a paracrine effector in pancreatic islet cell death after release from islet beta cells [3]. Consistent with this idea, we have shown that chelation of $\mathrm{Zn}^{2+}$ could decrease the development of diabetes after streptozotocin (STZ) treatment suggesting the role of $\mathrm{Zn}^{2+}$ release in the secondary islet cell death following direct primary death by STZ [3]. This idea was originally proposed in the central nervous system for neuronal death after cerebral ischaemia or prolonged seizures. In such models, $\mathrm{Zn}^{2+}$ concentrated in synaptic vesicles was considered to be translocated to degenerating postsynaptic neurons and 
chelation of released $\mathrm{Zn}^{2+}$ abrogated neuronal injury $[4,5,6]$. Whereas the mechanism of $\mathrm{Zn}^{2+}$-induced cell injury has not been clearly understood, recent papers suggested a possible role of disturbance in the energy metabolism in $\mathrm{Zn}^{2+}$-induced neuronal cell death because $\mathrm{Zn}^{2+}$ could inhibit key glycolytic enzymes such as glyceraldehyde-3-phosphate dehydrogenase (GAPDH) in vitro and $\mathrm{Zn}^{2+}$-induced neuronal cell death was decreased by pyruvate or other intermediates of glucose metabolism [7, 8]. However, other mechanisms such as repletion of $\mathrm{NAD}^{+}$or reactive oxygen species (ROS) scavenging by pyruvate have also been implicated.

We conducted this investigation to study if pyruvate could inhibit $\mathrm{Zn}^{2+}$-induced death of pancreatic beta cells. We further explored if pyruvate infusion could inhibit the development of diabetes after STZ treatment in which $\mathrm{Zn}^{2+}$ has been reported to play a role as a secondary death effector [3].

\section{Materials and methods}

MTT assay. As a model of pancreatic beta cells, SV40 T-transformed insulinoma cells derived from non-obese diabetic (NOD) mice [9] were used (MIN6N8). MIN6N8 cells were cultured in DMEM-15\% FCS containing $2 \mathrm{mmol} / \mathrm{l}$ glutamine and penicillin-streptomycin (Gibco-BRL, Gaithersburg, Md., USA). Cell death was measured using the 3-[4,5-dimethylthiazol-2yl]-2,5-diphenyltetrazolium bromide (MTT) (Sigma, St Louis, Mo., USA) assay. Cells were seeded in 96 -well plates $\left(3 \times 10^{4} /\right.$ well) and treated with $\mathrm{ZnCl}_{2}$ for $24 \mathrm{~h}$; then the medium was removed, and $100 \mu \mathrm{l}$ of $12.2 \mathrm{mmol} / \mathrm{l} \mathrm{MTT}$ solution was added to each well. After incubation at $37^{\circ} \mathrm{C}$ for $4 \mathrm{~h}$, crystals were precipitated by brief centrifugation. The crystals were dissolved in DMSO (Merck, Darmstadt, Germany), and absorbance at $570 \mathrm{~nm}$ was measured using an ELISA microplate reader (Molecular Devices, Sunnyvale, Calif., USA). Necrosis of ME-180 cervical cancer cells was induced by treating them with a combination of $100 \mathrm{U} / \mathrm{ml} \mathrm{IFN-} \gamma$ and $2700 \mathrm{U} / \mathrm{ml} \mathrm{TNF-} \alpha$ in the presence of $50 \mu \mathrm{mol} / \mathrm{l} N$-benzyloxycarbonyl-Val-Ala-Asp.fluoromethylketone (z-VAD.fmk) (Enzyme Systems, Livermore, Calif., USA) [10]. Recombinant human IFN- $\gamma$ was purchased from R\&D Systems (Minneapolis, Minn., USA). Recombinant human TNF- $\alpha$ was generously provided by Dr. T.H. Lee (Yonsei University, Seoul, Korea). All other chemicals were from Sigma unless stated otherwise.

Morphological analysis of dead cells. Cells were doublestained with $4.1 \mu \mathrm{mol} / 1$ Hoechst 33342 and $3.7 \mu \mathrm{mol} / 1$ propidium iodide (PI) (Molecular Probes, Eugene, Ore., USA) to distinguish apoptotic cells from necrotic cells. Cells with intact blue nuclei, condensed/fragmented nuclei and intact pink nuclei were considered as viable, apoptotic and necrotic cells, respectively [10].

Measurement of ATP contents. Intracellular ATP contents were measured using a commercial kit (Sigma). In brief, luminescence from ATP in cells lysed with a premade reagent was measured using a luminometer (Promega, Madison, Wis., USA). ATP contents in the sample were calculated as $\left(\mathrm{ATP}_{\text {Internal Standard }} \times \mathrm{L}_{\text {Sample }}\right) /\left(\mathrm{L}_{\text {Sample }}+\right.$ Internal Standard $\left.-\mathrm{L}_{\text {Sample }}\right)$.
Measurement of GAPDH activity. We added $25 \mu \mathrm{g}$ cytosolic sample protein to the $1 \mathrm{ml}$ reaction mixture containing $100 \mathrm{mmol} / \mathrm{l}$ sodium pyrophosphate, $\mathrm{pH} 8.5,20 \mathrm{mmol} / \mathrm{l}$ sodium phosphate, $0.25 \mathrm{mmol} / \mathrm{l} \mathrm{NAD}^{+}, 3 \mu \mathrm{mol} / 1$ dithiothreitol and $16 \mu \mathrm{mol} / 1$ glyceraldehydes-3-phosphate. After incubation at $25^{\circ} \mathrm{C}$ for $5 \mathrm{~min}$, absorbance at $340 \mathrm{~nm}$ was measured and NADH concentration was calculated according to Beer's law [11].

In vivo administration of pyruvate. STZ $(245.1 \mu \mathrm{mol} / \mathrm{kg}$ in $0.1 \mathrm{~mol} / \mathrm{l}$ citrate buffer, $\mathrm{pH} 4.5$ ) was injected intraperitoneally to Sprague-Dawley rats after overnight fasting. Pyruvate solution $(150 \mathrm{mmol} / \mathrm{l})$ was started through the tail vein $1 \mathrm{~h}$ before STZ injection and was continued for an additional $24 \mathrm{~h}$ at a rate of $3 \mathrm{ml} \cdot \mathrm{hour}^{-1} \cdot \mathrm{kg}^{-1}$. Control rats were infused with the same amount of normal saline. Glucose was added to the infusion solution $2 \mathrm{~h}$ after STZ administration. Blood glucose concentrations were measured using the glucose oxidase method. Non-fasting blood glucose concentrations above $14.4 \mathrm{mmol} / \mathrm{l}$ were considered diabetic. All animal experiments were conducted in accordance with an institutional guideline of Samsung Medical Center Animal Facility, an Association for Assessment and Accreditation for Laboratory Animal Care International-accredited facility.

Quantitation of beta-cell mass. Formalin-fixed sections of the rat pancreata were deparaffinized and briefly microwaved in $0.01 \mathrm{~mol} / \mathrm{l}$ sodium citrate buffer $(\mathrm{pH} 6.0)$. They were then incubated with an appropriate dilution of anti-porcine insulin antibody (Ab) (DAKO Japan, Kyoto, Japan) after goat serum blocking. Incubation with biotinylated anti-guinea pig $\operatorname{IgG~Ab}$, and then with avidin-biotin-peroxidase complex (Vector, Burlingame, Calif., USA) followed, diaminobenzidine was used as a colour substrate. Point counting morphometry on anti-insulin $\mathrm{Ab}$-stained sections was used to calculate the relative beta-cell volume as a measure of beta-cell mass after STZ treatment [12].

Statistical analysis. Binomial test was used to compare the incidences of diabetes between two groups. Student's $t$-test was used to compare the mean blood glucose concentrations or relative beta-cell volumes between the groups. Repeated measure analysis of variance (ANOVA) was used to test the effect of pyruvate infusion on the blood glucose concentrations at multiple points. In all cases of multiple statistical analyses, $p$ values were corrected by Bonferroni's method. $p$ values less than 0.05 were regarded as being statistically significant. All results were expressed as means $\pm \mathrm{SD}$. All in vitro experiments were carried out more than three times to ensure reproducibility of the experiments. As independent in vitro experiments showed similar tendency, intra-assay means \pm SD were used for statistical analysis.

\section{Results}

Inhibition of Zn2+-induced insulinoma cell necrosis by pyruvate. Firstly, we explored if pyruvate that has been reported to protect neuronal cells against $\mathrm{Zn}^{2+}$ induced death could affect $\mathrm{Zn}^{2+}$-induced death of MIN6N8 insulinoma cells. Two hundred $\mu \mathrm{mol} / 1 \mathrm{Zn}^{2+}$ induced death of MIN6N8 cells as reported (Fig. 1A). $\mathrm{Zn}^{2+}$-induced death of MIN6N8 cells was classical necrosis as shown by the uptake of PI without nuclear condensation/fragmentation in $86 \%$ of MIN6N8 cells treated with $200 \mu \mathrm{mol} / 1 \mathrm{Zn}^{2+}$ (Fig. 1B,C). Pyruvate decreased $\mathrm{Zn}^{2+}$-induced MIN6N8 cell death (necrosis) in 
A

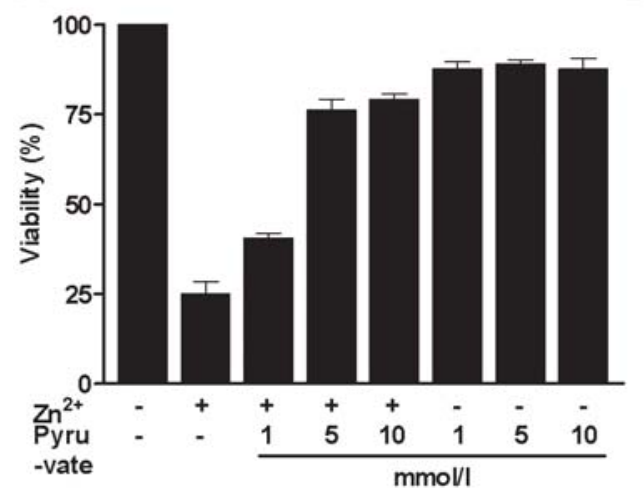

C

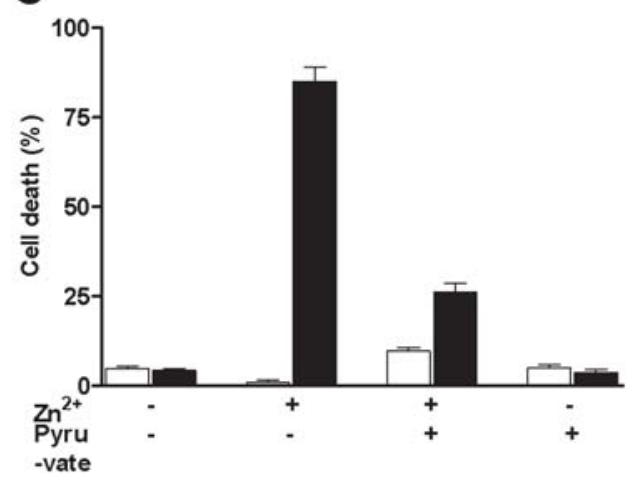

B

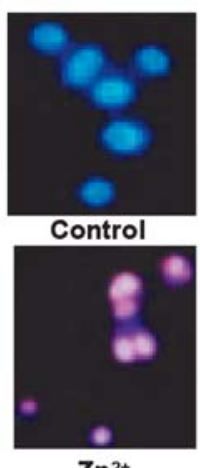

$\mathrm{Zn}^{2+}$

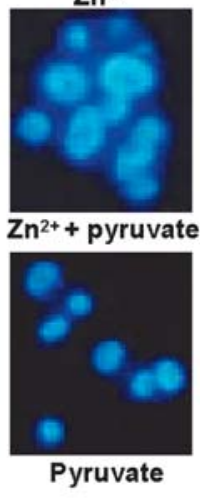

Fig. 1A-C. Abrogation of $\mathrm{Zn}^{2+}$-induced necrosis by pyruvate. (A) Pyruvate inhibited $\mathrm{Zn}^{2+}$-induced MIN6N8 cell death in a dose-dependent manner. (B, C) Hoechst 33342/ PI double staining $(\times 400)$ showed that $\mathrm{Zn}^{2+}$ exerted necrosis on MIN6N8 cells without apoptotic component, which was abrogated by pyruvate (white bars for apoptosis and black bars for necrosis). Results are representative of three or more independent experiments performed in triplicate, showing similar tendency

a dose-dependent manner and $10 \mathrm{mmol} / \mathrm{l}$ pyruvate inhibited more than $80 \%$ of insulinoma cell death by $\mathrm{Zn}^{2+}$ (Fig. 1A-C). We then studied if pyruvate could inhibit target cell death in other types of necrosis or apoptosis. Treatment with $15 \mathrm{mmol} / \mathrm{l} \mathrm{STZ}$ for $24 \mathrm{~h}$ induced death (mostly necrosis) of about $60 \%$ of insulinoma cells as identified by MTT assay and Hoechst 33342/PI double staining (Fig. 2). However, $10 \mathrm{mmol} / \mathrm{l}$ pyruvate did not inhibit MIN6N8 cells death by STZ. It also did not attenuate necrosis of ME-180 cervical cancer cells by IFN- $\gamma /$ TNF- $\alpha$ combination in the presence of z-VAD.fmk, while more than $75 \%$ of target cells underwent necrosis on Hoechst 33342/PI staining . Pyruvate did not inhibit apoptosis of insulinoma by $100 \mu \mathrm{mol} / \mathrm{l}$ etoposide or $1 \mu \mathrm{mol} / \mathrm{l}$ staurosporine, suggesting that the effect of pyruvate is specific for certain types of necrosis such as that induced by $\mathrm{Zn}^{2+}$ (Fig. 2).

Protection of intracellular energy metabolism by pyruvate. We also studied if $\mathrm{Zn}^{2+}$ or pyruvate affects the energy metabolism of MIN6N8 cells because $\mathrm{Zn}^{2+}$

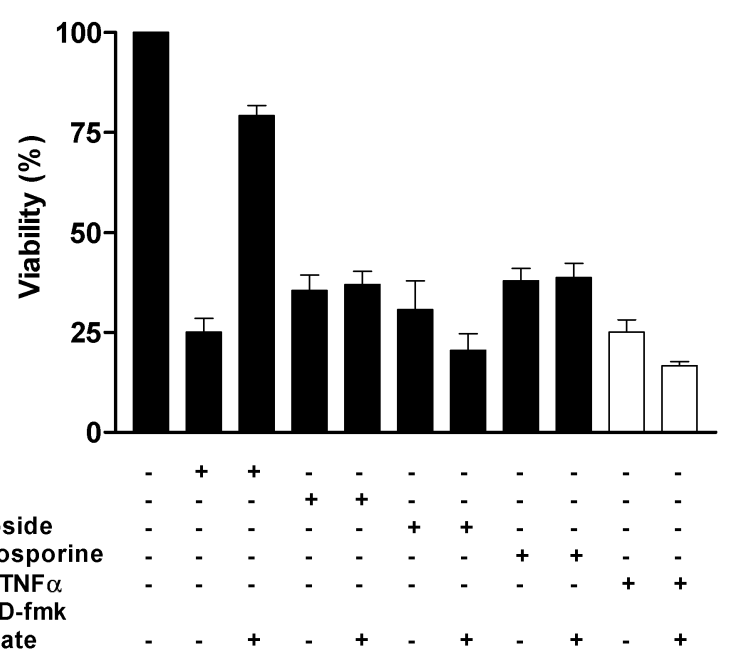

Fig. 2. Effects of pyruvate on other types of necrosis or apoptosis. Pyruvate failed to inhibit necrosis of MIN6N8 cells (black bars) by STZ or that of ME-180 cervical cancer cells (white bars) by IFN- $\gamma / \mathrm{TNF}-\alpha$ combination in the presence of z-VAD.fmk, a pancaspase inhibitor. Pyruvate also did not inhibit apoptosis of MIN6N8 cells by etoposide or staurosporine. Results are representative of three or more experiments carried out in triplicate

has been reported to inhibit glycolysis by blocking GAPDH. Treatment of MIN6N8 cells with $200 \mu \mathrm{mol}$ $\mathrm{Zn}^{2+}$ induced an abrupt decrease in ATP contents. Pyruvate dramatically inhibited the decrease in ATP contents by $\mathrm{Zn}^{2+}$ treatment, suggesting that failure in energy metabolism plays an important role in $\mathrm{Zn}^{2+}$-induced insulinoma cell death and pyruvate decreases $\mathrm{Zn}^{2+}$-induced cell death by normalizing the energy metabolism (Fig. 3A). The decrease in ATP contents of MIN6N8 cells after $\mathrm{Zn}^{2+}$ treatment and its rescue by pyruvate paralleled the temporal pattern of MIN6N8 cell death (Fig. 3B). To further prove that $\mathrm{Zn}^{2+}$ induces MIN6N8 cell death by inhibiting GAPDH and disrupting the energy metabolism, we directly measured GAPDH activity after $\mathrm{Zn}^{2+}$ treatment of MIN6N8 cells. As hypothesized, $\mathrm{Zn}^{2+}$ treatment for 6 to $24 \mathrm{~h}$ decreased GAPDH activity of MIN6N8 cells in a similar time frame (Fig. 3C).

As these results suggested the failure of ATP production as a probable cause of $\mathrm{Zn}^{2+}$-induced insulinoma cell death, we studied the effect of tricarboxylic acid (TCA) cycle intermediates on $\mathrm{Zn}^{2+}$-induced MIN6N8 cell death. The introduction of $10 \mathrm{mmol} / \mathrm{l}$ of oxaloacetate or $\alpha$-ketoglutarate increased MIN6N8 cell viability after $\mathrm{Zn}^{2+}$ treatment, suggesting that acute depletion of ATP is responsible for insulinoma cell necrosis after $\mathrm{Zn}^{2+}$ treatment and its correction protects them from $\mathrm{Zn}^{2+}$-induced necrosis (Fig. 4). Also $5 \mathrm{mmol} / \mathrm{l}$ dimethylester of another TCA cycle intermediate succinate (succinic acid dimethyl ester, SAD) that penetrates efficiently into pancreatic islet cells inhibited $\mathrm{Zn}^{2+}$-induced MIN6N8 cell death (Fig. 4). As pyruvate, oxaloacetate and $\alpha$-ketoglutarate 

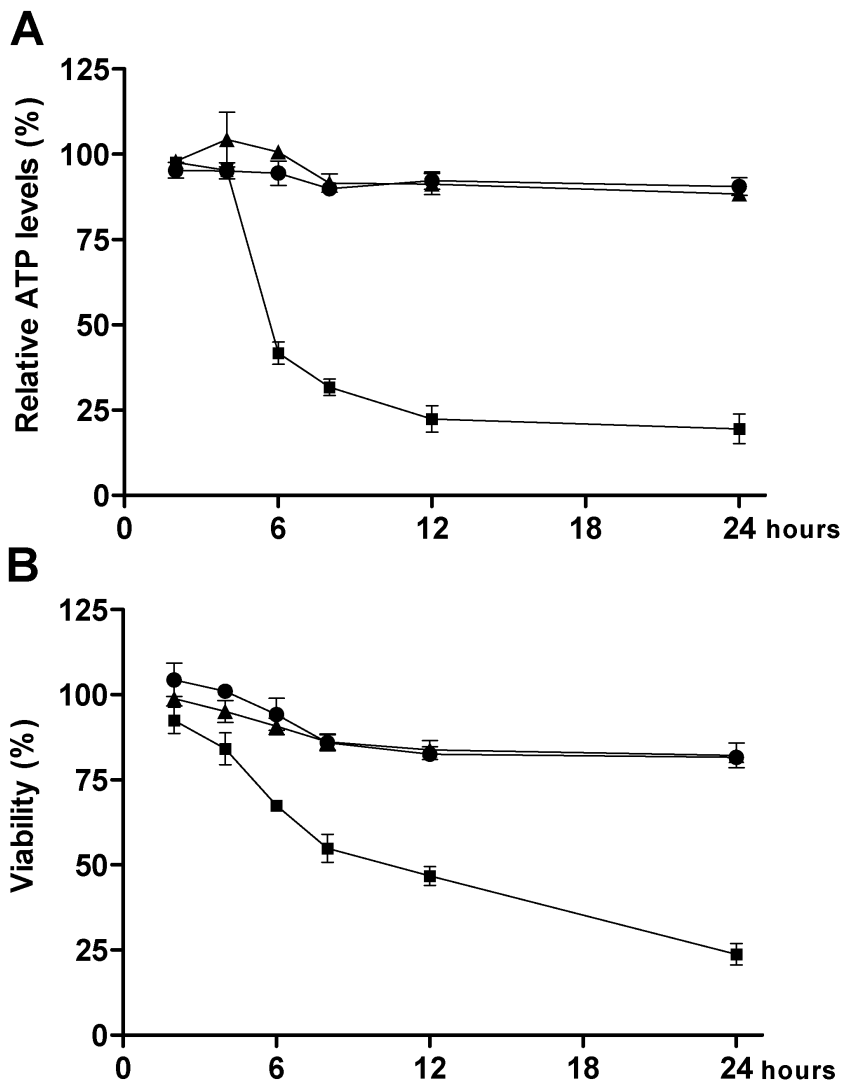

$\begin{array}{llllllllll}\mathrm{Zn}^{2+} & - & + & + & + & + & + & + & + & + \\ \text { Pyruvate } & - & - & + & - & - & - & - & - & - \\ \text { Oxaloacetate } & - & - & - & + & - & - & - & - & - \\ \alpha-\text { ketoglutarate } & - & - & - & - & + & - & - & - & - \\ \alpha-\text { ketobutyrate } & - & - & - & - & - & + & - & - & - \\ \text { SAD } & - & - & - & - & - & - & + & - & - \\ \text { BHA } & - & - & - & - & - & - & - & + & - \\ \text { Trolox } & - & - & - & - & - & - & - & - & +\end{array}$

Fig. 4. Effects of energy substrates and antioxidants on $\mathrm{Zn}^{2+}$ induced MIN6N8 cell death. Oxaloacetate, $\alpha$-ketoglutarate or $\mathrm{SAD}$ as TCA cycle intermediates or their cell-permeable ester substantially inhibited the necrosis of MIN6N8 cells by $\mathrm{Zn}^{2+}$, while antioxidants such as BHA, Trolox or $\alpha$-ketobutyrate did not notably affect their death compared to pyruvate, oxaloacetate or $\alpha$-ketoglurarate. Results are representative of three or more experiments carried out in triplicate

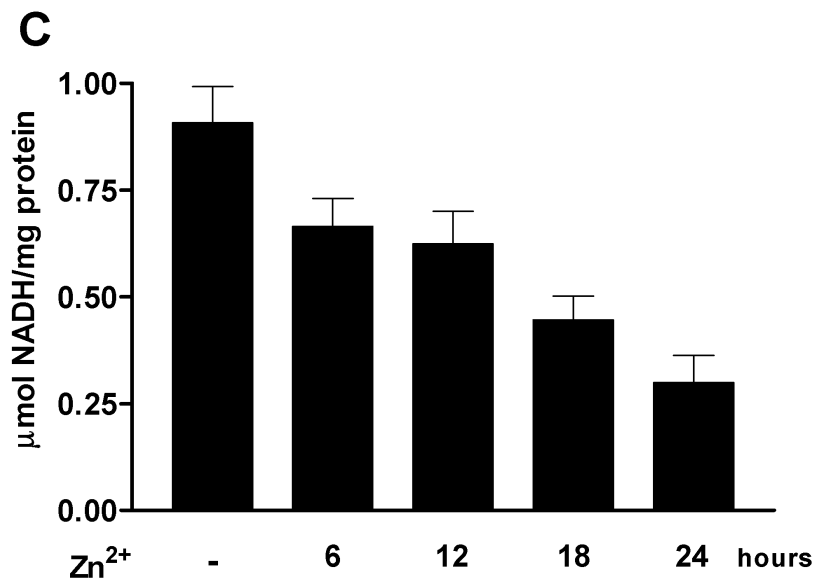

Fig. 3A-C. Effects of $\mathrm{Zn}^{2+}$ and pyruvate on intracellular ATP contents and GADPH activity. (A) $\mathrm{Zn}^{2+}$ (squares) induced a rapid decline of intracellular ATP contents, which was abrogated by the addition of pyruvate (triangles). Temporal change in ATP contents induced by $\mathrm{Zn}^{2+}$ and pyruvate $(\mathbf{A})$ paralleled that in MIN6N8 cell viability (B). Pyruvate alone (circles) did not significantly affect ATP contents or viability (A, B). (C) Treatment of MIN6N8 cells with $\mathrm{Zn}^{2+}$ decreased GAPDH activity in a similar time frame

are ROS scavengers and their protective effect might be related to the removal of oxygen radicals produced by $\mathrm{Zn}^{2+}$, we asked if antioxidants could inhibit $\mathrm{Zn}^{2+}$ induced insulinoma cell death. Classic antioxidants such as $100 \mu \mathrm{mol} / \mathrm{l}$ Trolox and $10 \mu \mathrm{mol} / \mathrm{l}$ butylated hydroxyanisole (BHA) did not significantly affect MIN6N8 cell death by $\mathrm{Zn}^{2+}$. In addition, the effect of

$\alpha$-ketobutyrate that has ROS scavenger properties but does not act as an energy substrate on $\mathrm{Zn}^{2+}$-induced MIN6N8 cell death was much less than that of pyruvate, oxaloacetate or $\alpha$-ketoglutarate, suggesting that the effect of pyruvate or TCA cycle intermediates is not related to the scavenging of oxygen radicals (Fig. 4).

As pyruvate could increase the cytoplasmic content of $\mathrm{NAD}^{+}$through its conversion to lactate in the presence of sufficient lactate dehydrogenase (LDH) and the increase in $\mathrm{NAD}^{+}$contents has been suggested to be an important mechanism of pyruvate-mediated protection of neuronal cells, we hypothesised if methylpyruvate that is not metabolized in cytoplasm but acts as an insulin secretagogue by generating ATP in mitochondria could protect insulinoma cells against $\mathrm{Zn}^{2+}$ induced necrosis. The addition of $10 \mathrm{mmol} / \mathrm{l}$ methylpyruvate abrogated $\mathrm{Zn}^{2+}$-induced insulinoma cell death like pyruvate (Fig. 5A). It also protected ATP levels in $\mathrm{Zn}^{2+}$-treated insulinoma cells, which suggests that the protective effect of pyruvate against $\mathrm{Zn}^{2+}$-induced insulinoma cell death is due to the restoration of ATP levels rather than an increase in $\mathrm{NAD}^{+}$contents and might be related to an insufficient LDH in islet/insulinoma cells (Fig. 5B). Additionally, 10 $\mathrm{mmol} / \mathrm{l} \alpha$-ketoisocaproate (KIC) that is exclusively metabolized in mitochondria and stimulates ATP production like methylpyruvate inhibited $\mathrm{Zn}^{2+}$-induced MIN6N8 cell death, indicating the role of ATP metabolism in $\mathrm{Zn}^{2+}$-induced insulinoma cell death. The addition of $10 \mathrm{mmol} / \mathrm{l}$ lactate that is not converted to pyruvate in insulinoma/islet cells because of insuffi- 
A

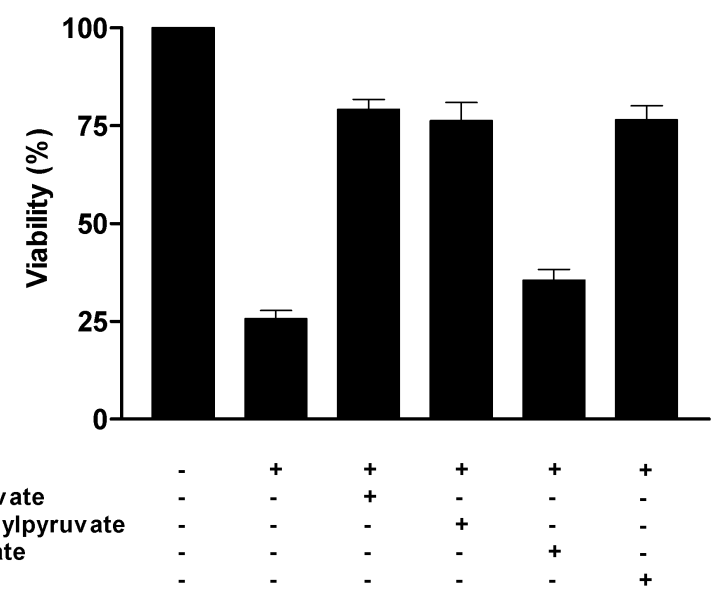

B

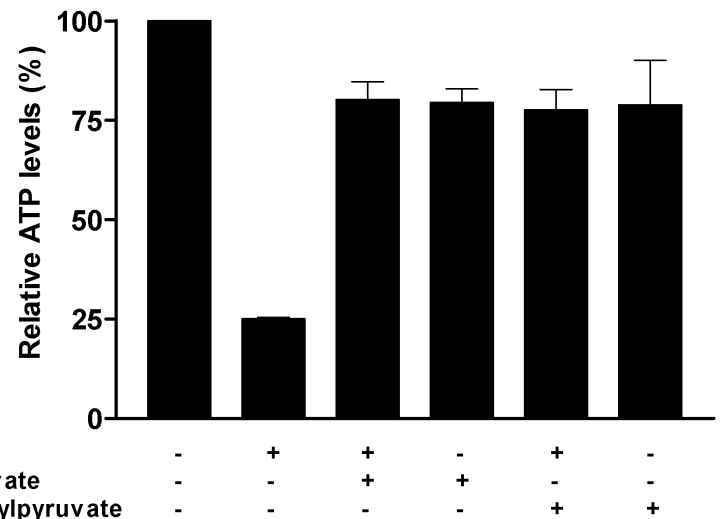

Fig. 5A, B. Inhibition of $\mathrm{Zn}^{2+}$-induced MIN6N8 cell death by methylpyruvate. (A) Methylpyruvate that is not metabolized in cytoplasm but generates ATP in mitochondria or KIC that is exclusively metabolized in mitochondria and stimulates ATP production abrogated MIN6N8 cell necrosis by $\mathrm{Zn}^{2+}$. (B) Methylpyruvate protected intracellular ATP contents after $\mathrm{Zn}^{2+}$ treatment as efficiently as pyruvate. Results are representative of three or more experiments carried out in triplicate

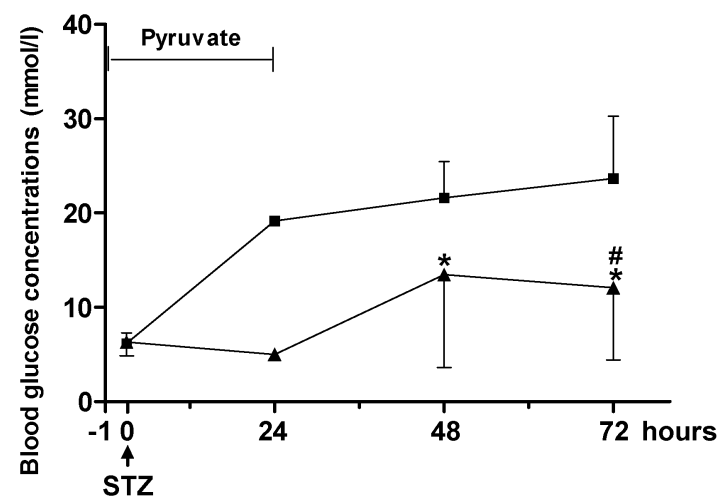

Fig. 6. Effects of in vivo pyruvate administration on STZinduced diabetes. Pyruvate infusion decreased the incidence of diabetes at $48 \mathrm{~h}$ and $72 \mathrm{~h}$ after STZ injection $(* p<0.05)$. Blood glucose concentrations at $72 \mathrm{~h}$ after STZ administration were also lower in pyruvate-infused rats (triangles) compared to control rats (squares) to which normal saline was infused ( ${ }^{\#} p<0.05$ )
A

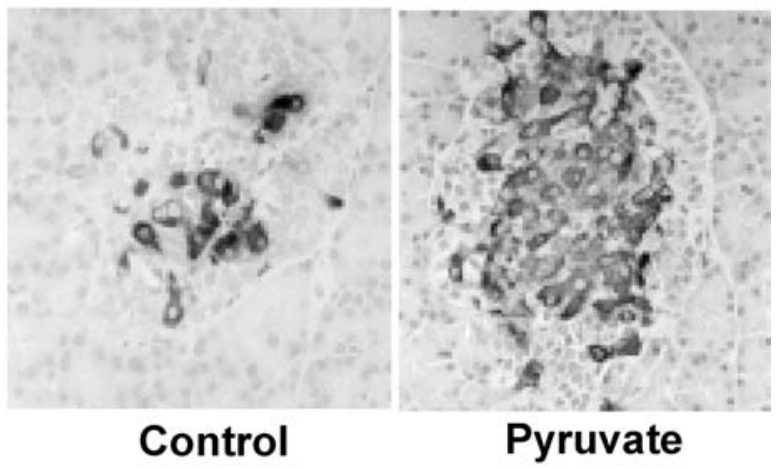

B

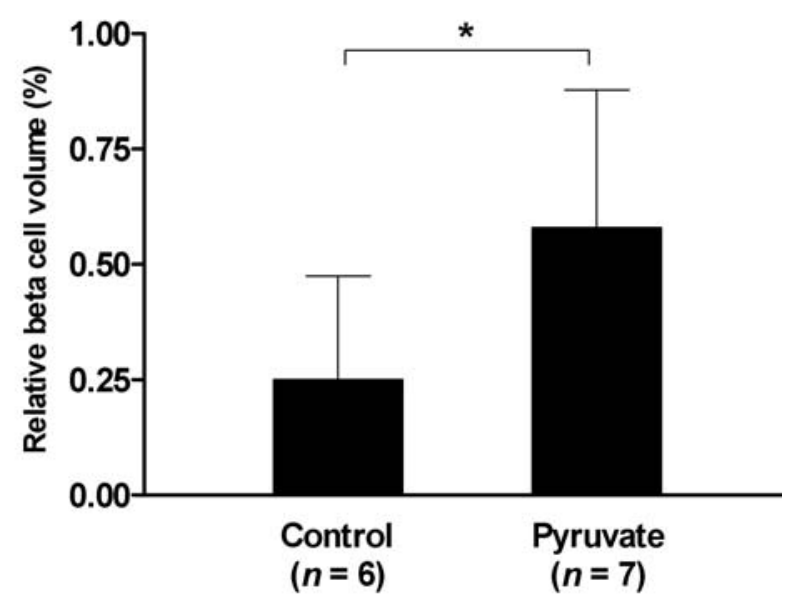

Fig. 7A, B. Attenuation of STZ-induced beta-cell injury by pyruvate infusion. Beta-cell volume measured by point counting of the cells stained with anti-insulin Ab 3 days after STZ treatment (A) was higher in pyruvate-infused rats compared to control rats $(* p<0.05)(\times 200)(\mathbf{B})$

cient $\mathrm{LDH}$ did not inhibit $\mathrm{Zn}^{2+}$-induced necrosis of insulinoma cells (Fig. 5A).

Inhibition of STZ-induced diabetes by pyruvate infusion. Finally, we studied if pyruvate could inhibit the development of diabetes after STZ administration that is considered to be partly mediated by $\mathrm{Zn}^{2+}$. All six control rats to which normal saline was infused became diabetic $48 \mathrm{~h}$ after intraperitoneal injection of STZ. In contrast, continuous pyruvate infusion for $24 \mathrm{~h}$ decreased the incidence of diabetes to $37.5 \%$ $(3 / 8)$ at both $48 \mathrm{~h}$ and $72 \mathrm{~h}$ after STZ treatment as revealed by binomial test with Bonferroni's correction $(p<0.05, p<0.05)$. When the blood glucose concentrations were compared, repeated measure ANOVA showed that general profile of the glucose levels was changed by pyruvate infusion $(p<0.05)$. Individual Student's $t$-test with Bonferroni's correction showed that the glucose levels were lower in pyruvate-infused rats $(n=8)$ compared to control rats $(n=6)$ at $72 \mathrm{~h}$ after STZ treatment $(12.1 \mathrm{mmol} / \mathrm{l} \pm 7.6 \mathrm{mmol} / \mathrm{l}$ vs $23.7 \mathrm{mmol} / \mathrm{l} \pm 6.6 \mathrm{mmol} / \mathrm{l})(p<0.05)$ (Fig. 6). At $48 \mathrm{~h}$, 
pyruvate infusion lowered glucose concentrations after STZ treatment but the difference was not statistically significant $(13.5 \pm 8.8 \mathrm{mmol} / \mathrm{l}$ vs $21.6 \pm$ $3.8 \mathrm{mmol} / \mathrm{l}, \quad p>0.1)$. The relative beta-cell volume 3 days after STZ treatment was $0.580 \pm 0.289 \%(n=7)$ in pyruvate-infused rats, which was higher than that in control rats $(0.250 \pm 0.224 \%, n=6)$ to which normal saline was infused $(p<0.05)$, suggesting that pyruvate inhibits diabetes after STZ treatment through the inhibition of islet cell death by $\mathrm{Zn}^{2+}$ released after the initial islet cell injury (Fig. 7A,B).

\section{Discussion}

We have shown that pyruvate inhibited insulinoma cell necrosis by $\mathrm{Zn}^{2+}$ in vitro, which is similar to the effect reported in central neurons [8]. Simple chelation of $\mathrm{Zn}^{2+}$ by pyruvate is unlikely because the log stability constant for zinc pyruvate is very low [21]. Pyruvate also has been reported to inhibit neuronal injury by death effectors other than $\mathrm{Zn}^{2+}[14,22]$ and reperfusion necrosis of cardiac cells $[23,24]$. An acute decrease in ATP contents by $\mathrm{Zn}^{2+}$ and its reversion by pyruvate observed in this investigation is consistent with previous papers showing the inhibition of GAPDH by $\mathrm{Zn}^{2+}$ in other types of cells $[7,8]$. Previous reports have suggested the role of ATP as a switch between apoptosis and necrosis in that depletion of ATP contents below 50\%, suppressed caspase activation and DNA fragmentation [25, 26]. Consistent with such contention, treatment of MIN6N8 cells with etoposide did not induce an early decrease in ATP contents, while it already exerted substantial apoptosis $12 \mathrm{~h}$ after treatment. However, other forms of necrosis were not inhibited by pyruvate such as STZ-induced insulinoma cell necrosis or cytokine-induced necrosis of ME-180 cells in the presence of caspase inhibitors [10]. The reason for the inhibition of only a certain type of necrosis by pyruvate is not clearly understood. While detailed biochemical consequences or pathways of necrosis are not clearly dissected, necrosis as a morphological definition could entail complex heterogeneous events. For instance, necrosis of beta islet cells by STZ is due to poly(ADP-ribose) polymerase (PARP) activation followed by $\mathrm{NAD}^{+}$depletion [27, 28], whereas that of lymphocytes or certain cancer cells by TNF family members without caspase activation reportedly involves receptor-interacting protein (RIP) or lysosomal protease such as cathepsin B [29, 30]. Thus, only a certain type of necrosis might be critically affected by pyruvate or specific energy substrates. Pyruvate also could be able to correct energy metabolism only in certain types of cells.

Our observation that TCA cycle intermediates such as oxaloacetate or $\alpha$-ketoglutarate inhibited $\mathrm{Zn}^{2+}$ mediated insulinoma cell necrosis further supports the critical role of energy metabolism in $\mathrm{Zn}^{2+}$-induced necrosis. SAD, an ester of another TCA cycle intermediate succinate, that efficiently penetrates into pancreatic islet cells and participates in energy metabolism [13] also inhibited insulinoma cell death by $\mathrm{Zn}^{2+}$. On the other hand, $\alpha$-ketobutyrate, a structural homologue of $\alpha$-ketoglutarate, which has ROS scavenging effect without metabolic function or other antioxidants such as BHA or Trolox failed to enhance insulinoma cell viability after $\mathrm{Zn}^{2+}$ treatment. These results suggest that ROS does not play an important role in $\mathrm{Zn}^{2+}$ induced necrosis of MIN6N8 cells. In contrast, previous papers reported roles for oxygen radicals in $\mathrm{Zn}^{2+}$ induced death of neuronal cells $[31,32]$ and the capability of pyruvate as an ROS scavenger [14]. These discrepancies might reflect the difference in the cell types studied. The role of $\mathrm{NAD}^{+}$as a mediator of protection by pyruvate against $\mathrm{Zn}^{2+}$-induced injury also has been reported in neuronal cells [8]. However, no substantial amount of $\mathrm{NAD}^{+}$is likely to be produced directly from pyruvate in islet/insulinoma cells because LDH is scarce in islet cells [18]. The protective effect of oxaloacetate or $\alpha$-ketoglutarate against $\mathrm{Zn}^{2+}$ mediated cell death also cannot be explained by the changes in intracellular NAD ${ }^{+}$levels. Nicotinamide or 3-aminobenzamide that inhibits STZ-induced islet cell death by inhibiting PARP and protecting NAD ${ }^{+}$levels $[27,28]$ also did not enhance insulinoma cell viability after $\mathrm{Zn}^{2+}$ treatment. If pyruvate protects insulinoma cells against $\mathrm{Zn}^{2+}$-induced necrosis by conserving energy metabolism, it should be in mitochondria and produce ATP. Pyruvate is able to penetrate into mitochondria $[18,33]$ and is well metabolized to yield ATP in islet cells $[15,33]$, which might be related to the low activity of LDH and high activity of mitochondrial glycerol phosphate dehydrogenase in islet cells allowing channeling of pyruvate and NADH toward mitochondrial oxidation $[16,17]$. Our observation that methylpyruvate inhibited $\mathrm{Zn}^{2+}$-induced decline in ATP levels as efficiently as pyruvate is consistent with previous reports showing similar levels of ATP production by pyruvate and methylpyruvate [33]. Furthermore, effective inhibition of $\mathrm{Zn}^{2+}$-induced insulinoma cell death by methylpyruvate suggest that pyruvate most likely inhibits $\mathrm{Zn}^{2+}$-induced insulinoma cell death by replenishing ATP rather than generating $\mathrm{NAD}^{+}$because methylpyruvate is known to enter mitochondria without metabolic conversion in cytoplasm and will not generate $\mathrm{NAD}^{+}$in cytoplasm [15]. Furthermore, KIC that directly stimulates ATP production in mitochondria $[19,20]$ also protected insulinoma cells from $\mathrm{Zn}^{2+}$-induced death. The inability of lactate to inhibit $\mathrm{Zn}^{2+}$-induced insulinoma cell death is similar to a previous paper using neuronal cells [8]. Particularly in islet cells, lactate is not easily converted to pyruvate due to the lack of LDH [18]. MIN6 insulinoma cells have also been reported to have much lower LDH activity compared to non-beta cells, albeit slightly higher when compared to beta cells $[16,34]$. 
Amelioration of STZ-induced diabetes by pyruvate infusion is similar to the protection of brain tissue by pyruvate against ischaemic injury [35]. The inhibition of STZ-induced diabetes by pyruvate infusion was not due to the possible effects of pyruvate on insulin secretion because the effect of pyruvate was observed even at $48 \mathrm{~h}$ after the cessation of pyruvate infusion (thus, at 72 hours after STZ treatment) and pyruvate is a relatively poor secretagogue of insulin secretion [33]. This result and our previous report that CaEDTA, a $\mathrm{Zn}^{2+}$ chelator, inhibited diabetes after STZ administration [3], suggests a role for $\mathrm{Zn}^{2+}$ released after primary islet insult in the development of STZinduced diabetes. While $\mathrm{Zn}^{2+}$ is not the primary effector for islet cell death in STZ-induced diabetes and pyruvate does not affect islet cell death by STZ, $\mathrm{Zn}^{2+}$ liberated from secretory granules of beta cells might aggravate beta-cell destruction and contribute to the development of diabetes.

Acknowledgements. This work was supported by Science Research Center Grants from the Korea Science \& Engineering Foundation and Health Planning Technology \& Evaluation Board Grants (02-PJ1-PG1-CH04-0001). M.-S. Lee is an awardee of the National Research Laboratory Grants from the Korea Institute of Science \& Technology Evaluation and Planning (2000-N-NL-01-C-232).

\section{References}

1. Huang XF, Arvan P (1995) Intracellular transport of proinsulin in pancreatic $\beta$-cells. J Biol Chem 270:2041720423

2. Zawelski PD, Millard SH, Forbes IJ et al. (1994) Video analysis of labile zinc in viable pancreatic islet cells using a specific fluorescence probe for zinc. J Histochem Cytochem 42:877-884

3. Kim BJ, Kim YH, Kim S et al. (2000) Zinc as a paracrine effector in pancreatic islet cell death. Diabetes 49:367372

4. Frederickson CJ, Hernandez MD, McGinty JF (1989) Translocation of zinc may contribute to seizure-induced death of neurons. Brain Res 480:317-321

5. Tonder N, Johansen FF, Frederickson CJ, Zimmer J, Diemer NH (1990) Possible role of zinc in the selective degeneration of dentate hilar neurons after cerebral ischemia in the adult rat. Neurosci Lett 109:247-252

6. Koh J-Y, W SS, Gwag BJ, He YY, Hsu CY, Choi DW (1996) The role of zinc in selective neuronal death after transient global cerebral ischemia. Science 272:1013-1016

7. Krotkiewska B, Banas T (1992) Interaction of $\mathrm{Zn}^{2+}$ and $\mathrm{Cu}^{2+}$ ions with glyceraldehyde-3-phosphate dehydrogenase from bovine heart and rabbit muscle. Int $\mathrm{J}$ Biochem 24:1501-1505

8. Sheline CT, Behrens MM, Choi DW (2000) Zinc-induced cortical neuronal death: contribution of energy failure attributable to loss of $\mathrm{NAD}^{+}$and inhibition of glycolysis. J Neurosci 20:3139-3146

9. Yagi N, Yokono K, Amano K et al. (1995) Expression of intercellular adhesion molecule 1 on pancreatic $\beta$-cells accelerates $\beta$-cell destruction by cytotoxic T-cells in murine autoimmune diabetes. Diabetes 44:744-752
10. Suk K, Chang I, Kim YH et al. (2001) IFN $\gamma / \mathrm{TNF} \alpha$ synergism in ME-180 cervical cancer cell apoptosis and necrosis: IFN $\gamma$ inhibits cytoprotective NF-kappaB through STAT1/IRF-1 pathways. J Biol Chem 276:13153-13159

11. Mazzola JL, Sirover MA (2003) Subcellular alteration of glyceraldehyde-3-phosphate dehydrogenase in Alzheimer's disease fibroblasts. J Neurosci Res 71:279-285

12. Montana E, Bonner-Weir S, Weir GC (1993) Beta cell mass and growth after syngeneic islet cell transplantation in normal and streptozotocin diabetic C57BL/6 mice. J Clin Invest 91:780-787

13. Malaisse WJ, Sener A (1993) Metabolic effects and fate of succinate esters in pancreatic islets. Am J Physiol 264:E434-E440

14. Desagher S, Glowinski J, Premont J (1997) Pyruvate protects neurons against hydrogen peroxide-induced toxicity. J Neurosci 17:9060-9067

15. Mertz RJ, Worley JF, Spencer B, Johnson JH, Dukes ID (1996) Activation of stimulus-secretion coupling in pancreatic $\beta$-cells by specific products of glucose metabolism. J Biol Chem 271:4838-4845

16. Sekine N, Cirulli V, Regazzi R et al. (1994) Low lactate dehydrogenase and high mitochondrial glycerol phosphate dehydrogenase in pancreatic $\beta$-cells. J Biol Chem 269:4895-4902

17. Alcazar O, Tiedge M, Lenzen S (2000) Importance of lactate dehydrogenase for the regulation of glycolytic flux and insulin secretion in insulin-producing cells. Biochem $\mathrm{J}$ 352:373-380

18. Ishihara H, Wang H, Drewes LR, Wollheim CB (1999) Overexpression of monocarboxylate transporter and lactate dehydrogenase alters insulin secretory responses to pyruvate and lactate in $\beta$ cells. J Clin Invest 104:1621-1629

19. Panten U, Christians J, Kriegstein EV, Poser W, Hasselblatt A (1974) Studies on the mechanism of L-leucine-and $\alpha$-ketoisocaproic acid-induced insulin release from perifused isolated pancreatic islets. Diabetologia 10:149154

20. Hutton JC, Sener A, Herchuelz A et al. (1980) Similarities in the stimulus-secretion coupling mechanisms of glucoseand 2-keto acid-induced insulin release. Endocrinology 106:203-219

21. Martell AE (1972) First stability constant of various metal chelates. CRC handbook of food additives, Chap. 6. CRC Press, West Palm Beach, Fla.

22. Ruiz F, Alvarez G, Pereira R et al. (1998) Protection by pyruvate and malate against glutamate-mediated neurotoxicity. Neuroreport 9:1277-1282

23. Halestrap AP, Kerr PM, Javadov S, Woodfield K, Y. (1998) Elucidating the molecular mechanism of the permeability transition pore and its role in reperfusion injury of the heart. Biochim Biophys Acta 1366:79-94

24. Kerr PM, Suleiman MS, Halestrap AP (1999) Reversal of permeability transition during recovery of hearts from ischemia and its enhancement by pyruvate. Am J Physiol 45:H496-H502

25. Eguchi Y, Shimizu S, Tsujimoto Y (1997) Intracellular ATP levels determine cell death fate by apoptosis or necrosis. Cancer Res 57:1835-1840

26. Leist M, Single B, Castoldi AF, Kuhnle S, Nicotera P (1997) Intracellular adenosine triphosphate (ATP) concentration:a switch in the decision between apoptosis and necrosis. J Exp Med 185:1481-1486

27. Burkart V, Wang ZQ, Radons J et al. (1999) Mice lacking the poly(ADP-ribose) polymerase gene are resistant to pancreatic beta-cell destruction and diabetes development induced by streptozotocin. Nat Med 5:314-319 
28. Hoorens A, Pipeleers D (1999) Nicotinamide protects human beta cells against chemically-induced necrosis, but not against cytokine-induced apoptosis. Diabetologia 42:52-59

29. Holler N, Zaru R, Micheau O et al. (2000) Fas triggers an alternative, caspase-8-indenpendent cell death pathway using the kinase RIP as effector molecule. Cancer Res 1:489-495

30. Nakayama M, Ishidoh K, Kayagaki N et al. (2002) Multiple pathways of TWEAK-induced cell death. J Immunol 168:734-743

31. Sensi SL, Yin HZ, Carriedo SG, Rao SS, Weiss JH (1999) Preferential $\mathrm{Zn}^{2+}$ influx through $\mathrm{Ca}^{2+}$-permeable AMPA/ kainate channels triggers prolonged mitochondrial superoxide production. Proc Natl Acad Sci USA 96:2414-2419
32. Kim EY, Koh J-Y, H. KY, Sohn S, Joe E, Gwag BJ (1999) $\mathrm{Zn}^{2+}$ entry produces oxidative neuronal necrosis in cortical cell cultures. Eur J Neurosci 11:327-334

33. Lembert N, Joos HC, Idahl L-A, Ammon HPT, Wahl MA (2001) Methyl pyruvate initiates membrane depolarization and insulin release by metabolic factors other than ATP. Biochem J 354:345-350

34. Zhao C, Rutter GA (1998) Overexpression of lactate dehydrogenase A attenuates glucose-induced insulin secretion in stable MIN-6 $\beta$-cell lines. FEBS Lett 430:213216

35. Lee J-Y, Kim Y-H, Koh J-Y (2001) Protection by pyruvate against transient forebrain ischemia in rats. J Neurosci 21:RC171 